DOI: 10.17707/AgricultForest.61.1.16

\author{
Rada BRDAR, Ana PESIC, \\ Aleksandar JOKSIMOVIC, Zdravko IKICA, Danilo MRDAK, \\ Revilija MOZURAITYTE, UIf ERIKSON, Ekrem MISIMI ${ }^{I}$
}

\title{
QUALITY AND YIELD CHANGES IN RAINBOW TROUT DURING THE PROCESS OF HOT SMOKING: COMPARISON OF USING FRESH AND FROZEN RAW MATERIALS
}

\begin{abstract}
SUMMARY
This paper presents the results of physical and chemical changes that occur during the process of hot smoking of rainbow trout (Oncorhynchusmykiss), including differences occurring when using fresh or frozen/thawed fish as raw material for the same process. Fresh fish were gutted and subjected to temperature 'shocking' $\left(-35^{\circ} \mathrm{C}\right.$ for $\left.3.5 \mathrm{~h}\right)$ before salting in a $2 \% \mathrm{NaCl}$ solution for $12 \mathrm{~h}$. The fish were subsequently smoked at $75-80{ }^{\circ} \mathrm{C}$ for $2 \mathrm{~h}$. All material for analysis, 92 fishes, was provided by the private company "AHILEAS", Podgorica (Montenegro), and analysis were made following processing steps used in this company in the process of hot smoking. Water content, water holding capacity, $\mathrm{pH}$ and yield were determined before processing, after salting, and after smoking. The possible effect of using frozen/thawed fish as raw material was studied by freezing $\left(-17^{\circ} \mathrm{C}, 30\right.$ days) a group of the fresh gutted fish. After slow thawing, the fish were processed similar to the fresh raw material. Results of the performed analysis indicate that freezing of fish has no influence on the quality and yield of final, smoked product. The research was performed as a part of the SEAMED project, financed by the Norwegian ministry of foreign affairs through HERD (High Education and Research for Development) programme for West Balkans.

Keywords: fish processing, water content, water holding capacity, yield.
\end{abstract}

\section{INTRODUCTION}

Fish processing implies applications of preserving techniques in order to maintain the quality of the product and extend its shelf life. In preservation of fish products, techniques based on temperature control, ice, cooling and/or freezing, as well as other techniques based on water activity control (including drying, salting, smoking and lyophilisation) are used (http://www.fao.org/docrep/003/v3630e/v3630e03.htm).

\footnotetext{
${ }^{1}$ Rada BRDAR, Ana PESIC (corresponding author: pesica@ac.me), Aleksandar JOKSIMOVIC, Zdravko IKICA, University of Montenegro Institute of Marine Biology, Kotor, MONTENEGRO, Danilo MRDAK, University of Montenegro, Faculty of Biology, Podgorica, MONTENEGRO, Revilija MOZURAITYTE, Ulf ERIKSON, Ekrem MISIMI, SINTEF Fisheries and Aquaculture, Trondheim, NORWAY.

Paper presented at the $5^{\text {th }}$ International Scientific Agricultural Symposium "AGROSYM 2014".

Notes: The authors declare that they have no conflicts of interest. Authorship Form signed online.
} 
Smoking is a preserving method in which raw materials are exposed to products of wood burning, i.e. smoke ingredients. Through smoking the fish dehydrates and its mass is accordingly reduced. Enzyme inactivation occurs, and heat causes modifications to proteins and lipids. Dehydration, impregnation of fish with smoke components and addition of salt lead to the significant reduction of water activity. Such product has satisfying nutritional values, as well as the sensory quality, will preserve better and has longer shelf life (Doe, 1998). Traditional fish preservation techniques include drying, salting and smoking. In modern times, drying and smoking products are obtained through the use of automated equipment with temperature and humidity control (Burgess et al., 1965).

Water activity (aw) is lowered with water content reduction and increase of osmotic pressure. With water activity reduction, partial water vapor pressure is also reduced, freezing point drops, boiling point increases and development of microorganisms is reduced or stopped. Water activity is used as a measure of potential microorganism growth, that is ratio of water vapor pressure above the ingredients $(\mathrm{P})$ and water vapor pressure above pure water at the same temperature $(\mathrm{Po}), \mathrm{Aw}=\mathrm{P} / \mathrm{Po}$. Concentration of water or dry matter can also be used for this purpose (Vereš, 2004).Water activity is one of the most important factors in determining the quality and safety of food. It affects the shelf life, how well it keeps food texture, aroma and smell. By measuring the aw values, it is possible to predict which microorganisms could be the potential source of food spoilage. In addition to helping determine the influence of microbial organisms on food, aw value play an important role in determination of enzyme activity, vitamin degradation, lipid oxidation and other processes occurring in food (Josefsen, 2012).

Water content is directly related to water activity. Through the water holding capacity, texture of the meat is monitored, showing the capacity of fish muscle tissue to hold a certain amount of water as well as the physical and chemical parameters of fish flesh (Ramon, 2005). $\mathrm{pH}$ is an indicator of the volume of microbial activity in fish flesh, i.e. spoilage, as proteolytic microorganisms produce acid after dissolving carbohydrates, which increases the acidity of the environment (Eyo, 1993). The yield is important from the economic standpoint (Gallart-Jornet et al., 2007) and is dependent on the preservation technology, salt content, time and temperature of smoking. Salt contents have a positive effect on yield increase, as it causes water retention in tissue and according weight increase (Ramon, 2005), while hot smoking causes a reduction in yield due to high temperatures involved.

\section{MATERIAL AND METHODS}

Analyses have been performed on fish samples in the "Ahileas" company. The technological process of fish preservation in this company is made of the following stages: 1) Washing and cleaning of the fish immediately after delivery; 2) Cold-shocking in shock-tunnel at temperatures of $-35^{\circ} \mathrm{C}$ lasting for 3.5 hours; 
3) Immersion in brine $\left(2 \% \mathrm{NaCl}\right.$ solution) at temperature of $0^{\circ} \mathrm{C}$ lasting for 12 hours; 4) Smoking at temperatures of $75-80^{\circ} \mathrm{C}$ for 2 hours in the automated ATMUS machine. During the smoking process, beech shavings are used as beech lends typical color, taste and aroma to the finished product. The fish is then sealed in vacuum packaging and stored at $0^{\circ} \mathrm{C}$ until distribution to the market.

The analyses have been performed on a total of 92 specimens of rainbow trout (Oncorhynchus mykiss). One part of the sample (48 specimens) was immediately processed, while the remaining 44 specimens were stored for 30 days at temperature of $-17^{\circ} \mathrm{C}$. After the storage, the samples were processed identically to the fresh specimens. Each specimen was marked and followed through the preservation process. During the preservation process, the fish have been sampled at every step of the process: fresh, after cold-shocking, brineimmersed and smoked. Four samples have been taken at each step and analyzed for water content, water holding capacity, $\mathrm{pH}$-value and yield. The analyses were performed at the Institute of Marine Biology in Kotor.

Each specimen was weighted in fresh state, after cold-shocking, after immersion in brine and after smoking, and those measurements were used in yield determination during the preservation process. Weight measuring was performed using "SARTORIUS" electronic balance, with precision of $0.01 \mathrm{~g}$.

For water content determination, bones and skin were removed from the samples, which were then processed in kitchen blender in order to obtain a homogenous mass. Four samples of trout were sampled from each step in the preservation process in order to obtain the average water content for each step. Water content was determined by drying $2 \mathrm{~g}$ of sample at $105^{\circ} \mathrm{C}$ for 18 hours.

Water holding capacity (WHC) was determined through centrifugal force by measuring $2 \mathrm{~g}$ of sample in a perforated cuvette (perforations from 90 to 100 $\mu \mathrm{m})$ and centrifuged at $2000 \mathrm{r} / \mathrm{min}$ for 5 minutes (Eideet all., 1982). Three repetitions of the analysis were performed for each sample in order to minimize errors.

The $\mathrm{pH}$-value was measured in trout filets using the standard $\mathrm{pH}$-meter with glass electrode (TW ProfiLine pH 3210), at three points: near the head of the fish, at mid-point and close to the caudal fin. Based on the measurements, mean value of $\mathrm{pH}$ in tissue of a single fish was determined. Also, at every step of the preservation process 4 specimens were sampled on which a mean $\mathrm{pH}$ value was determined for each step (fresh, cold-shocked/frozen, immersed in brine, smoked).

\section{RESULTS AND DISCUSSION}

This study followed the changes in water concentration in trout muscle during the smoking process and compared the use of fresh and frozen fish in preservation.

Water content in trout tissue was determined in all technological steps during preservation and smoking process in fresh and frozen samples in order to 
determine whether there are quality differences between the two. The results are shown in Table 1 and Figure 1.

Table 1.Percentual values of water content during the process of preservation

\begin{tabular}{|l|r|r|r|r|}
\cline { 2 - 5 } \multicolumn{1}{c|}{} & \multicolumn{4}{c|}{ Technological steps during preservation process } \\
\hline Trout & Fresh & Cold-shocked & Immersed in brine & \multicolumn{1}{l|}{ Smoked } \\
\hline Fresh & 74.38 & 75.22 & 76.25 & 69.82 \\
\hline Frozen & 74.38 & 73.38 & 75.80 & 71.47 \\
\hline
\end{tabular}

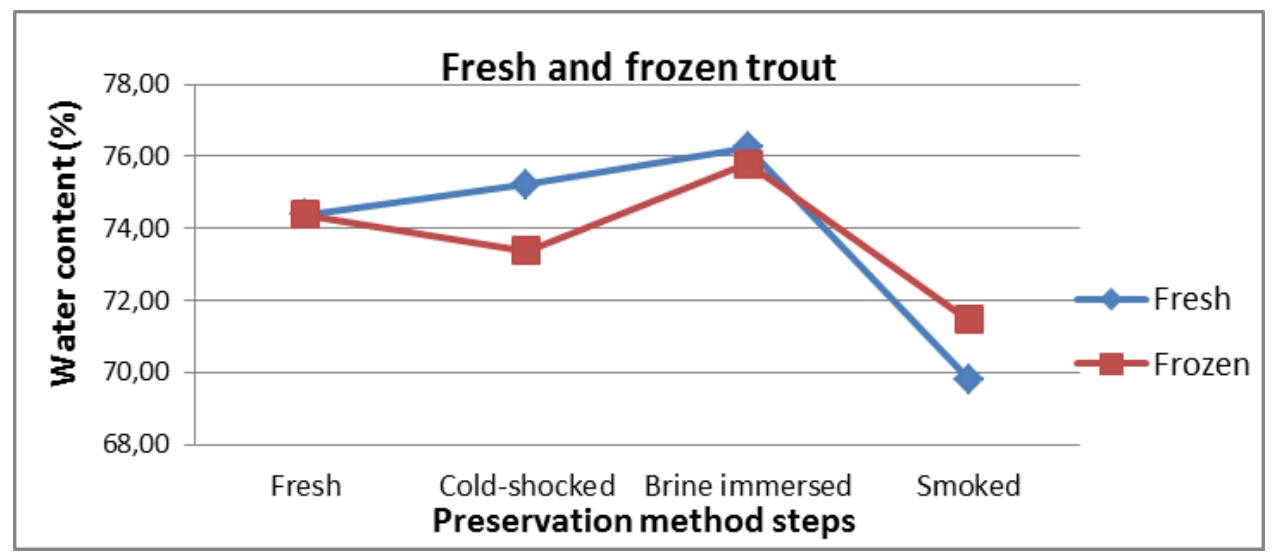

Figure 1. Water content changes in fresh and frozen tissue during the preservation process

Water content during smoking preservation process increases during coldshocking and reaches its maximum after immersion in brine, due to the swelling of tissue in salt solution (2-5\% salt) as water binds to myosin (Sigurgisladottir et al., 2000). During the smoking process there is a significant reduction in water content under the influence of drying and smoking. Frozen trout shows a similar trend, except after the step 2, after freezing, when the water content is lower. In actuality, deep freezing causes crystallisation of water in trout cells, which causes greater water loss after thawing, or dehydration. Water content in smoked products doesn't show significant differences between fresh and frozen trout.

Comparison of WHC changes between fresh and frozen trout during the smoking preservation process is show in Table 2 and Figure 2.

Table 2. Average WHC values during trout preservation process

\begin{tabular}{|l|l|l|l|l|}
\hline & \multicolumn{4}{|c|}{ Technological steps during preservation process } \\
\hline Trout & Fresh & Cold-shocked & Immersed in brine & Smoked \\
\hline Fresh & 79.87 & 80.40 & 83.09 & 77.06 \\
\hline Frozen & 79.87 & 93.91 & 95.35 & 80.94 \\
\hline
\end{tabular}




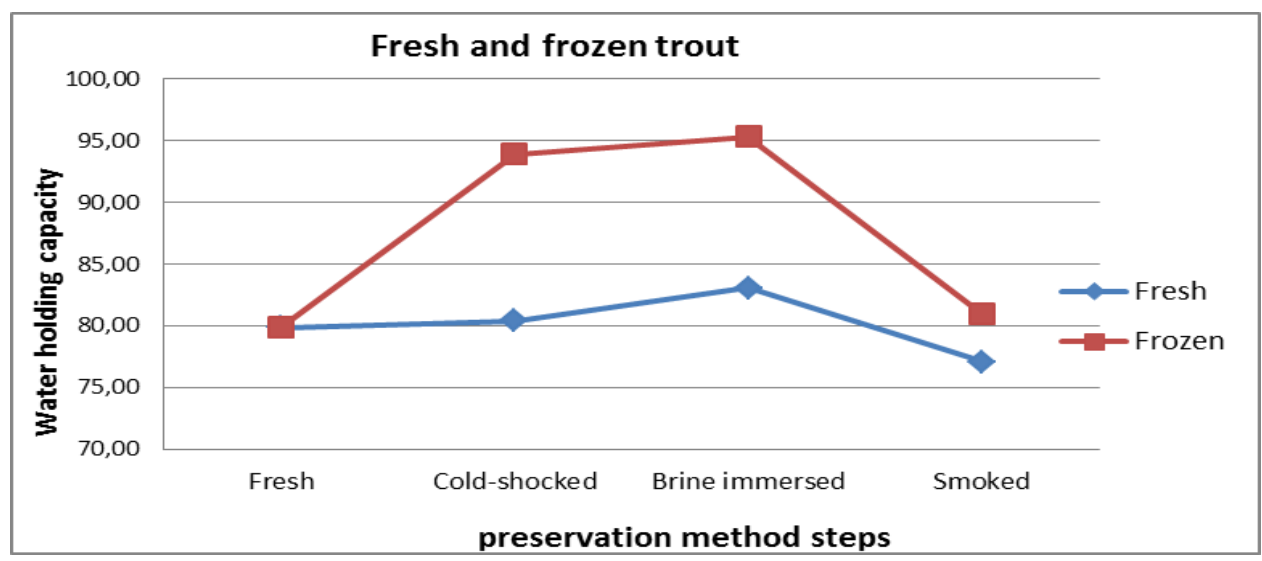

Figure 2. Comparison of water holding capacity change between fresh and frozen trout during the smoking preservation process

WHC significantly increases after brine immersion, under the influence of salt. Salt content of up to $2 \%$ leads to the increase of WHC in fish flesh (Regensteinand Regenstein, 1984). Figure 2 shows greater WHC in frozen trout compared to fresh fish. Freezing leads to higher brine absorption (probably due to changes at cellular level), resulting in the higher amount of salt in tissue which causes greater water retention, i.e. higher WHC (http://www.fao.org/docrep/003/v3630e/v3630e03.htm). Smoking causes significant loss of water under high temperatures required for smoking, and the WHC is reduced accordingly. Comparison of $\mathrm{pH}$ value changes in fresh and frozen trout tissue during the smoking preservation process is shown in Table 3 and Figure 3.

The $\mathrm{pH}$ values during smoking process for both fresh and frozen trout are within expected limits ( $\mathrm{pH}$ between 6 and 8 are expected values for fish). Differences in values between fresh and frozen trout during the preservation process were very slight, which can serve as proof of good sanitary quality of fish and the manufacturing process.

Yield was determined by measuring the weight of each specimen of frozen and fresh trout at every step of preservation process. Average values of changes in weight during the preservation process for fresh and frozen trout are shown in Table 4, as well as the comparison of weights of fresh and frozen specimens during the smoking process (Figure 4).

Table 3.Average $\mathrm{pH}$ values during trout preservation process

\begin{tabular}{|l|c|c|c|c|}
\hline & \multicolumn{4}{|c|}{ Technological steps during preservation process } \\
\hline Trout & Fresh & Cold-shocked & Immersed in brine & Smoked \\
\hline Fresh & 6.3 & 7.2 & 6.7 & 6.8 \\
\hline Frozen & 6.3 & 6.4 & 6.3 & 7 \\
\hline
\end{tabular}




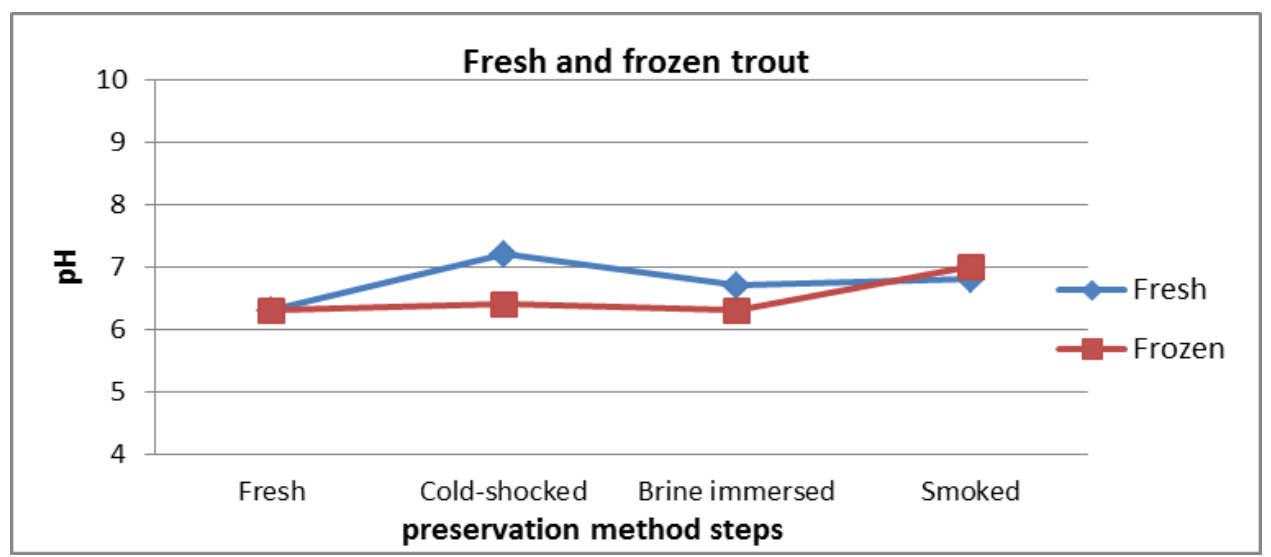

Figure 3. Comparison of $\mathrm{pH}$ value changes in fresh and frozen trout tissue during the smoking preservation process

Table 4.Average values of change in weight during the trout smoking process

\begin{tabular}{|l|c|c|c|c|}
\hline & \multicolumn{4}{|c|}{ Technological steps during preservation process } \\
\hline Trout & Fresh & Cold-shocked & Immersed in brine & Smoked \\
\hline Fresh & 207.52 & 206.84 & 214.39 & 167.35 \\
\hline Frozen & 206.60 & 189.04 & 204.55 & 167.09 \\
\hline
\end{tabular}

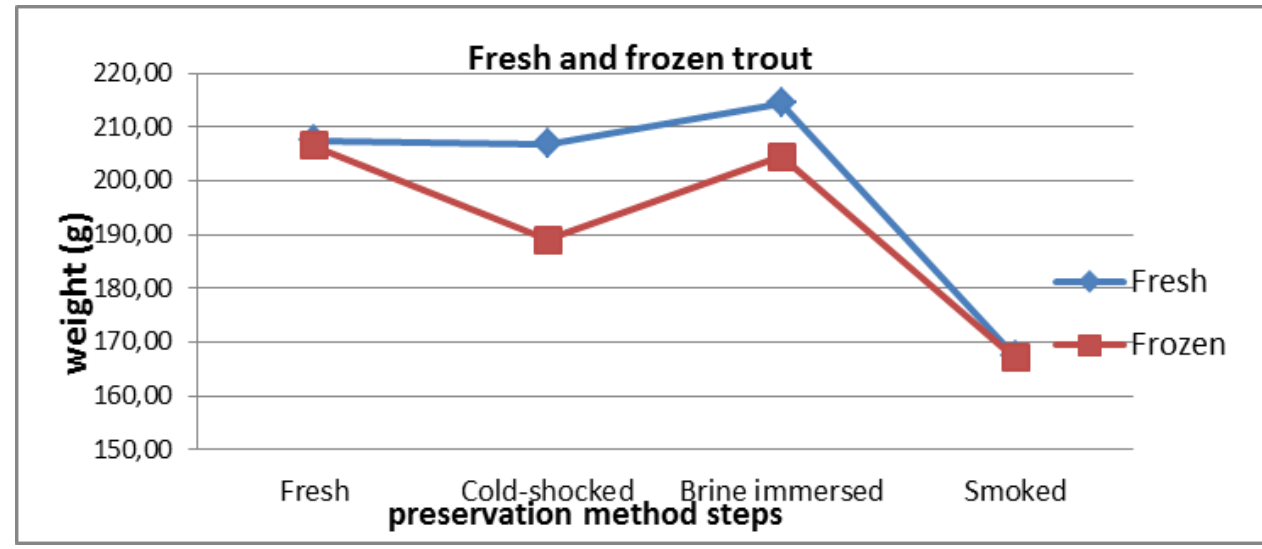

Figure 4. Comparison of weights of fresh and frozen trout during the smoking preservation process

Using fresh fish in the smoking preservation process increases the yield during the brine immersion step. The salt content has positive influence on yield, causes water retention in tissue which increases weight (Ramon, 2005).After smoking at high temperatures, large amount of water evaporates and significant weight loss occurs. During the preservation process, greater variations in weight were recorded in frozen samples compared to fresh ones. During the freezing process, tissue dehydration occurs and subsequent weight loss. During the brine immersion process, weight increases due to water absorbed in trout tissue (just 
like fresh specimens), and then during the smoking process the yield is reduced significantly compared to the fresh specimens during the first step of the preservation process. Weight of specimens at the end of the preservation process, i.e. smoked fish, was almost identical, showing that the choice between fresh and frozen fish doesn't affect the expected yield.

\section{CONCLUSIONS}

During the smoking preservation process of fish changes in water content, WHC and yield occur. Significant increase in water content values, WHC and yield in Step 3 - brine immersion is caused by effect the salt has on tissue. Fish tissue swells in brine solution (2-5\% salt) as water ties to myosin. After smoking trout tissue loses a significant amount of water, which leads to decrease of WHC and yield, which causes reduced water activity and increases quality of the product, keeping and shelf life. During each step of the process, the $\mathrm{pH}$ value was within expected limits and does not increase, which proves microbial safety and product quality. This study has shown no significant difference in use of fresh or frozen fish for the preservation process, and that studied parameters had almost identical values in the final, smoked product.

\section{REFERENCES}

Burgess, G.H.O., Cutting, C.L., Lovern, J.A., Waterman, J.,(1965).Fish Handling \& Processing, Edinburgh her majesty's stationery office.

Doe, P.E. b.Sc., Ph.D., F.I.E.Aust, (1998). Fish drying \& smoking production and quality, University of Tasmania.

Eide, O., Børresen, T., Strøm, T., (1982). Minced fish production from capelin (Mallotusvillosus).A new method for gutting, skinning and removal of fat from small fatty fish species, J Food Sci, Vol47, 347-349.

Eyo, A.A.,(1993). Traditional and improved fish handling, preservation and processing Techniques. Paper presented at National workshop on fish processing storage, marketing and utilization.

Gallart-Jornet, L., Barata, J.M., Rustad, T., Erikson, U., Escriche, I., Fito, P., (2007). Influence of brine concentration on Atlantic salmon fillet salting, Journal of Food Engineering, Vol. 80, Issue 1, 267-275.

Josefsen, K.D., (2012). Salt, water activity and microbial growth, SINTEF Material and Chemistri, Biotechnology, Trondheim.

Ramon, M., (2005).Effects of thermal modifications on the rheological characteristics and protein quality of three species of fish of varying collagen content, School of Industrial Fisheries Cochin University of Science and Technology (CUSAT), Kerala, India.

Regenstein, J.M., Regenstein, C.E., (1984). Food protein chemistry: an introduction for food scientist, Academic Press. Orlando. FL.

Sigurgisladottir, S., Sigurdardottir, M., Torrissen, O., Vallet, J.L., Hafsteinsson, H., (2000).Effects of different salting and smoking processes on the microstructure, the texture and yield of Atlantic salmon(Salmosalar) fillets, Food Research International, Vol. 33, 847-855.

Vereš, M., 2004.Principikonzervisanjanamirnica, Poljoprivrednifakultet,Univerzitet u Beogradu(Principles of food preservation, Faculty of Agriculture, University of Belgrade).

http://www.fao.org/docrep/003/v3630e/v3630e03.htm (date of accession March 2014). 